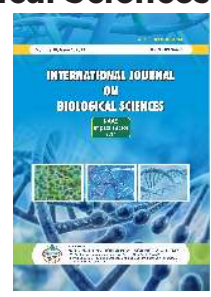

\title{
HYDROBIOLOGY OF PANDEY TAAL, A WETLAND OF GONDA DISTRICT, U.P., INDIA
}

\author{
${ }^{1}$ Mukul Sinha and ${ }^{2 *}$ Sharwan Kumar Srivastava \\ ${ }^{1}$ Department of Zoology and ${ }^{2}$ Department of Botany \\ Shri Lal Bahadur Shastri Degree College, Gonda, U.P.
}

\section{Research Paper}

Received: 01.10.2021

Revised: 14.10.2021

Accepted: 29.10.2021

\begin{abstract}
The physico-chemical condition of water plays a vital role in the aquatic ecosystem. The various physico-chemical parameters of water of Pandey Taal have been studied during July, 2019 to June, 2020 to find out its impact on planktonic population and fish culture. The authors recorded that water temperature ranges from $11.8-35.8^{\circ} \mathrm{C}$, transparency ranges from 27.6-37.8 cm, $\mathrm{pH}$ ranges from 7.0-8.8, dissolved oxygen ranges from 6.2-8.6 ppm, free carbon dioxide ranges from 15.2-28.8 ppm, total alkalinity ranges between 130.0 and $290.0 \mathrm{ppm}$, total hardness ranges between 75.0 and $120 \mathrm{ppm}$, nitrate ranges between 1.03 and $1.21 \mathrm{ppm}$ and phosphate ranges from 1.00-1.05 ppm. The physico-chemical conditions were found suitable for fish culture.
\end{abstract}

Keywords: Hydrobiology, Fish, Pandey Taal.

\section{INTRODUCTION}

Wetlands are very productive ecosystems, which help in the regulation of biological cycles, maintenance of water quality, nutrient movement and support for food chains (Prakash, 2020a \& b). Wetlands are important components of watersheds and provide many valuable functions to the environment and society (Prakash and Verma, 2019). The water resource is being used for various purposes such as domestic use, agriculture and fish culture etc. by local community. Now wetlands are shrinking rapidly because of urbanization and industrialization. Due to urbanization and anthropogenic pressure most of the wetlands are succumbed to greater degree of biologically active nutrient accumulation (Verma and Prakash, 2018). Review of literature revealed that several workers did researches on limnology and biodiversity diversity of different water bodies including Bhagde et al. (2020), Prakash et al. (2002, 2015a, b \& c and 2020), Verma et al. (2016a \& b), Sugumaran et al. (2020), Ranjan and Kushwaha (2020), Verma (2016 \& 2019) and Sinha et al. (2002) and so on. In future, there will be a threat of contamination of water from the surface runoff. The physico-chemical characters of the any water body can be used to assess its ecological nature. Although extensive works on the physico-chemical parameters of wetlands (Taal) have already been carried out but till now there is no sufficient baseline data about limnological parameters of Pandey Taal water, hence the authors have undertaken for studying the limnological characteristics in relation to fish culture.

\section{MATERIALS AND METHODS}

The Pandey Taal under exploration is a natural wetland situated in Gonda district of Davipatan division of Uttar Pradesh. The Taal is situated in city of Gonda more than 2 $\mathrm{km}$ away from Gonda railway station. It is situated between the latitude $27.40374^{\circ} \mathrm{N}-81.9535^{\circ} \mathrm{E}$. The Taal is enriched with several type of vegetation. The water of Taal is used for fish culture. The margin of the Taal is heavily infested by aquatic weeds and the organic deposition causes sedimentation of the Taal.

*Corresponding author: sksrivastava62@gmail.com 


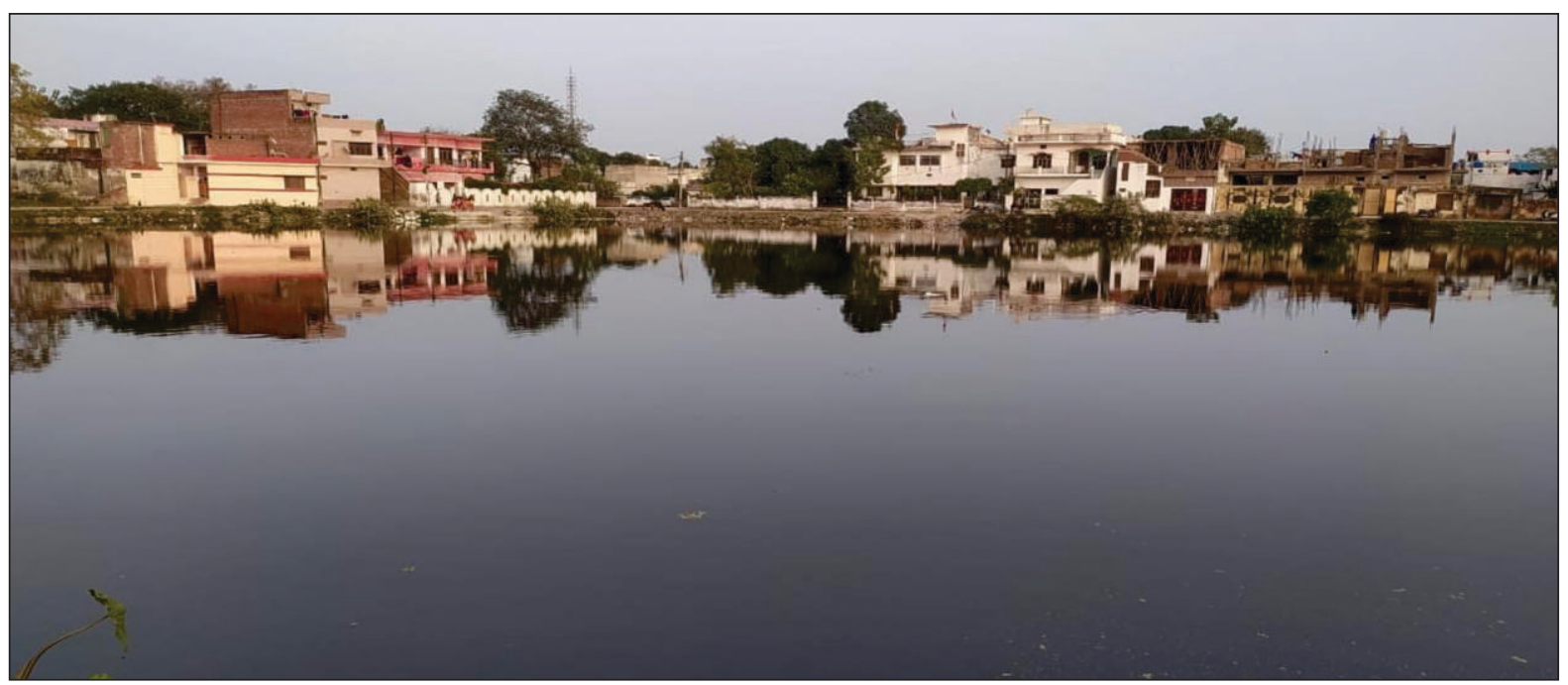

Fig. : Pandey Taal of Gonda District of Davipatan Division of U.P.

Water samples were collected fortnightly from three different sites in a plastic stoppered bottles, The temperature, dissolved oxygen, free carbon dioxide and $\mathrm{pH}$ recorded on spot by using water quality analyzer kit. The total alkalinity, total hardness, nitrates and phosphates analysis were made at field as well as in laboratory as per standard methods (APHA, 2005). In biological parameters, plankton productivity was measured by using Sedgewick Rafter plankton counting cell and quantities are expressed here as units per liter of the pond water.

Plankton were identified with the help of a book entitled "A guide to the study of fresh water biology" written by Needham and Needham (1962) and other standard literature.

\section{RESULTS AND DISCUSSION}

Results of the physico-chemical attributes of the taal water is given in Table 1 .

Water temperature influences the physiological activities of aquatic organisms. The water temperature of Taal ranged from $11.8-35.8^{\circ} \mathrm{C}$ during the study period. The range of water temperature is suitable for culture of fish culture (Jhingran, 1988). In the present study, maximum temperature was recorded during summer months followed by rainy whereas the minimum temperature during winter. Monthly variations noted in water temperature is a consequence of fluctuations in ambient temperature as the Taal represent smaller body of water in comparison to lakes and river and more quickly react to changes in atmospheric temperature (Verma and Prakash, 2020).

Water transparency controls the energy relationship at different trophic levels in food chain. The water transparency of Taal was ranged from 27.6-37.8 cm. The highest transparency was noted during winter seasons followed by rainy and summer seasons. Lower transparency observed during summer may be due to high planktonic population (Kumari and Jha 2015). Maximum transparency during winter may be due to sedimentation of suspended particles (Verma and Prakash, 2020).

$\mathrm{pH}$ is one of the most important parameters in water chemistry and is defined as negative logarithm of hydrogen ion concentration and measured as intensity of acidity or alkalinity on a scale ranging from $0-14$. The $\mathrm{pH}$ is an indicator of overall environmental condition of the aquatic system. The $\mathrm{pH}$ of Taal water ranged from 7.1-9.8. $\mathrm{pH}$ value during summer and lowest during rainy season and may be attributed to productive capacity of the Taal. The alkaline nature of water is suitable for aquatic life (Singh, 1990).

Analysis of dissolved oxygen of any water body is an important parameter because it serves as indicator of the physical, chemical and biological activities of that water body. The DO of Taal ranged between 6.2 and 8.6 ppm shows that it is good for fish culture. The highest dissolved oxygen was recorded during winter months may be attributed to high photosynthetic activity during 
these months. Oxygen is more soluble in cold water. Ansari and Prakash (2000) stated that the highest dissolved oxygen in winter may be due to low atmospheric temperature and minimum dissolved oxygen in summer may be due to high metabolic rate of organisms. Oxygen depletion in rainy season may be due to the low photosynthetic or respiratory activity of heterotrophic organisms and also probably due to the biological oxidation of organic matter and the combined effects of temperature and photosynthetic activity.

Free carbon dioxide in a water body is generally derived from the atmospheric sources, biotic respiration and decomposition of organic matter by saprophytes. In the present study, the $\mathrm{FCO}_{2}$ was ranged between 15.2 and $28.8 \mathrm{ppm}$. The $\mathrm{FCO}_{2}$ concentration in the Taal was maximum during rainy months and minimum during winter months. The appearance of high concentration of free carbon dioxide during monsoon months could probably be associated with active decomposition of organic matter. The present finding is similar to that of Kumar et al. (2015).
Alkalinity is directly related to the productivity of water bodies because it regulates the $\mathrm{pH}$ and free carbon dioxide of the water bodies. Bicarbonates and carbonates in most of natural water are responsible for alkalinity. The total alkalinity ranged between 130.0 and $290.0 \mathrm{ppm}$ indicates that the water of the Taal is nutrient rich as well as high productive (Alikunhi, 1957; Singh, 1990; Ansari and Prakash, 2000). The maximum alkalinity was in rainy season and minimum during winter season.

The total hardness is defined as the sum of calcium and magnesium carbonate concentrations in water. It is an index of fertility of the aquatic ecosystem. The total hardness ranged between 75-120 ppm indicates that water of the Taal is suitable for fish culture (Jhingran, 1988; Verma, 2020). The highest hardness was noticed in in winter months and lowest in rainy months. The result is supported by the findings of Kumar et al. (2015).

Table 1: Monthly variations in Physico-chemical properties of water of Pandey Taal, Gonda.

\begin{tabular}{|l|c|c|c|c|c|c|c|c|c|}
\hline Months & Temp. $\left({ }^{0} \mathbf{C}\right)$ & Trans. $(\mathbf{c m})$ & $\mathbf{p H}$ & $\begin{array}{c}\text { DO } \\
(\mathbf{p p m})\end{array}$ & $\begin{array}{c}\mathbf{F C O}_{2} \\
(\mathbf{p p m})\end{array}$ & $\begin{array}{c}\text { Total } \\
\text { Alk.(ppm) }\end{array}$ & $\begin{array}{c}\text { T H } \\
(\mathbf{p p m})\end{array}$ & $\begin{array}{c}\text { Nitrate } \\
(\mathbf{p p m})\end{array}$ & $\begin{array}{c}\text { Phosphate } \\
(\mathbf{p p m})\end{array}$ \\
\hline Jul. & 35.8 & 33.6 & 7.0 & 7.9 & 16.7 & 260.0 & 84.0 & 1.22 & 1.04 \\
\hline Aug. & 31.6 & 32.8 & 7.2 & 7.1 & 18.0 & 290.0 & 77.0 & 1.18 & 1.03 \\
\hline Sep. & 27.3 & 32.6 & 7.2 & 7.6 & 22.1 & 142.5 & 83.0 & 1.03 & 1.04 \\
\hline Oct. & 24.5 & 33.8 & 7.3 & 8.1 & 25.0 & 157.0 & 89.0 & 1.06 & 1.03 \\
\hline Nov. & 18.7 & 34.3 & 7.5 & 8.2 & 28.8 & 130.0 & 111.0 & 1.10 & 1.04 \\
\hline Dec. & 14.4 & 36.8 & 7.7 & 8.4 & 15.2 & 211.0 & 108.0 & 1.12 & 1.00 \\
\hline Jan. & 11.8 & 37.8 & 7.8 & 8.3 & 15.1 & 210.0 & 103.0 & 1.18 & 1.03 \\
\hline Feb. & 15.9 & 35.6 & 7.6 & 8.6 & 15.3 & 218.0 & 120.0 & 1.21 & 1.04 \\
\hline Mar. & 20.9 & 30.4 & 8.2 & 8.5 & 15.4 & 224.0 & 112.0 & 1.21 & 1.05 \\
\hline Apr. & 27.6 & 30.5 & 8.5 & 7.2 & 15.6 & 221.0 & 118.0 & 1.21 & 1.04 \\
\hline May. & 30.8 & 29.3 & 8.6 & 6.2 & 16.4 & 213.0 & 99.0 & 1.11 & 1.05 \\
\hline Jun. & 32.5 & 27.6 & 8.8 & 6.3 & 16.5 & 244.0 & 94.0 & 1.17 & 1.05 \\
\hline Ranges & $11.8-$ & $27.6-$ & $7.0-$ & $6.2-$ & $15.2-$ & $130.0-$ & $75-$ & $1.03-$ & $1.00-$ \\
\hline
\end{tabular}

The most chemically stable available form of nitrogen is nitrate. High nitrate concentration is responsible for algal blooms in water body. Surface runoff, decayed vegetation and animal matter are the main sources of nitrates in water body. The nitrate content of the water ranged between 1.03 and $1.21 \mathrm{ppm}$. Its maximum 
concentration was observed in the post monsoon season. The result is supported by the findings of Khan etal. (1986).

Phosphate is considered as the most critical nutrient substance in the maintenance of pond productivity. They are essential for the growth of organisms and a nutrient that limits the primary productivity of the water body. In the present study the phosphate content was ranged between 1.00-1.05 ppm. It was minimum during winter months and maximum during the summer months. Low phosphate contents during winter months and high during summer or post monsoon months may be due to low decomposition of organic matters during summer season (Prakash, 2001b).

\section{CONCLUSION}

Thus, it can be concluded that in spite of favorable physico- chemical condition of water, potential fish yield is not being realized. Fish production can be augmented to a great extent if we managed scientifically. It can be realized optimally by stocking of fast growing Indian major carps, Catla, Rohu, Mrigal and Calbasu in ratio 4:3:3 or by stocking of Indian major carp and exotic carp in ratio 3:3:2:2 for Catla, Rohu, Mrigal and Common carp, respectively @ 10000 fingerlings/ha to utilize the natural fish food resources.

\section{ACKNOWLEDGEMENTS}

Authors are highly grateful to the Principal Shri Lal Bahadur Shastri Degree College, Gonda (U.P.) for providing necessary laboratory facilities.

\section{REFERENCES}

1. Alikunhi, K.H. (1957). Fish culture technique in India. Prog. Fish Developm. India: 63-67.

2. Ansari, K.K. and Prakash, S. (2000). Limnological studies on Tulsidas Tal of tarai region of Balrampur in relation to fisheries. Poll. Res.19(4): 651-655.

3. АРНА (2005). Standard methods for Examination of water and waste water. American Public Health Association 21st Ed. APHA, New York.

4. Bhagde R. V., Pingle S. A., Bhoye M. R., Pansambal S. S. and Deshmukh D. R. (2020). A Comparative Study of Physico-Chemical Parameters of the Freshwater Ponds from
Sangamner Taluka of Ahmednagar, Maharashtra, India. International Journal of Biological Innovations. 2(2): 137-142. https://doi.org/ 10.46505/IJBI.2020.2209.

5. Jhingran, V.G. (1988). Fish and fisheries of India. Hindustan Publishing Corporation, India, pp 666.

6. Khan, E., Kaiser, U.M., Habib, M.A.B. and Hasan, M.R. (1986). Interrelations and interrelations and intrarelations of some water characteristics of a farm pond and meterologiacl factor. Bangladesh, J. Agric. 11 (4): 35-40.

7. Kumar, P.S., Satpathi, M. and Singh, R. (2015). Seasonal phytoplankton diversity of Perennial pond of Chaibasa, West Singhbhum at Jharkhand in India. Proc.Zool.Soc. India.14 (2): 19-25.

8. Kumar, U., Choudhary, S., Kumar, M. and Paswan, R. (2015). Physico-chemical Prameters of Gamhi water body of the Kaula Chaur (Wetland) Of Begusarai District (Bihar). Proc. Zool. Soc. India.14(1):1-6.

9. Kumari, C. and Jha, B.K. (2015). Health status of lentic waterbodies of Twin-City of DarbhangaLaheriasari (Bihar) with reference to seasonal variation in the physic-chemical characteristics. Proc.Zool.Soc.India.14(1):7-14.

10. Needham, J.J and Needham, P.R. (1962). A Guide to the study of freshwater Biology, Charles Cthomas Publisher, USA.

11. Prakash, S. (2001a). Seasonal dynamic of plankton in a fresh waterbody at Balrampur. GEOBIOS. 28(1):29-32.

12. Prakash, S. (2001b). Utilization of Brick- Kiln land in aquaculture. GEOBIOS. 28(4):193-196.

13. Prakash, S. (2020a). Fish diversity of Semara Taal, A wetland of district Siddharthnagar (U.P.), India. International Journal of Fisheries and Aquatic Research. (2020). 5(2): 7-9

14. Prakash, S. (2020b). Conservation status of Fishes reported from Semara Taal of district Siddharthnagar (U.P.), India. International Journal of Fauna and Biological Studies. (2020). 7(3): 21-24.

15. Prakash, S., Ansari, K.K. and Sinha, M. (2002). Seasonal dynamics of zooplankton in a fresh water pond developed from the wasteland of brick-kiln. Poll. Res. 21 (1): 81-83. 
16. Prakash S., Verma A.K., and Prakash S. (2015a). Limnological Studies of Alwara Lake of Kaushambi (U.P.). International Journal on Biological Sciences. 6(2):141-144.

17. Prakash S., Verma A.K., Prakash S. (2015b). Seasonal variation of Zooplankton and Zoobenthos Population in Alwara lake of District Kaushambi (UP) India. The Journal of Zoology Studies, 2(5), 13-16.

18. Prakash S. and Verma D. R. (2019). Preliminary Studies on Diversity of Aquatic Insects in Guthia Taal, a Wetland of district Bahraich, U.P. International Journal of Biological Innovations. 1(2): 78-82. https://doi.org/ 10.46505/ IJBI.2019.1208.

19. Prakash S., Verma A.K., Kumar S. and Mishra B.K. (2015c). Monthlies variations in phytoplankton density in Alwara lake of DistrictKaushambi (U.P.). Global Journal for Research Analysis, 4(12), DOI: 10.15373/ 22778160/ December2015/62.

20. Prakash S., Kumar A., Prakash S. and Mishra B.K. (2020). A Survey of Fish Fauna of Rapti River, Balrampur (U.P.), India. International Journal of Biological Innovations. 2(1): 76-81. https://doi.org/10.46505/IJBI.2020.2110.

21. Ranjan R. and Kushwaha A. (2020). Seasonal variation in Primary Productivity and Macrophytes of Guthia Taal, Bahraich (U.P.). International Journal of Biological Innovations. 2 (2): 236-240. https://doi.org/ 10.46505/ IJBI.2020.2221.

22. Singh, B. (1990). Limnology of a tropical pond with reference to fisheries. Recent Trends in Liminology. 415-425.

23. Sinha, M., Prakash, S. and Ansari, K.K. (2002). Seasonal dynamics of phytoplankton population in relation to abiotic factors of a fresh water pond developed from wasteland of brick-kiln. Asian Jr. of Microbiol. Biotech. Env. Sc. 4(1):43-45.

24. Sugumaran E., Shabeen B. and Radhakrishnan M. V. (2020). Zooplankton Diversity in Sathanur Reservoir of Thiruvannamalai (Tamilnadu), India. International Journal of Biological Innovations. 2 (2): 95-101. https://doi.org/ 10.46505/ IJBI. 2020.2203 .

25. Verma A.K. (2016). Hydrobiological Studies of Muntjibpur Pond of Allahabad (U.P.). International Journal on Agricultural Sciences. 7 (2):164-166.

26. Verma A.K. (2019). Studies of Hydrobiological Properties of Balapur Pond of Prayagraj (U.P.). Hortflora Research Spectrum. 8(1): 9-11.

27. Verma A.K. (2020). Limnological Studies of Muntjibpur pond of Prayagraj (U.P.) in relation to planktons. International Journal of Fauna and Biological Studies. 7 (4): 27-30.

28. Verma A.K., Prakash S. and Mishra B.K. (2016a). Phytoplankton diversity in Alwara lake of district Kaushambi (U.P.). Journal of Entomology and Zoology Studies. 4(1): 170-172.

29. Verma A.K., Kumar S. and Prakash S. (2016b). Seasonal Correlation between physico-chemical factors and phytoplankton density in Alwara Taal of Kaushambi, U. P., India. International Research Journal of Biological Sciences. 5(3):4045.

30. Verma, A.K. and Prakash, S. (2018). Qualitative and quantitative analysis of macrozoobenthos of Beghel Taal, a wetland of U.P. Indian Journal of Biology. 5 (2): 127-130.

31. Verma, A.K. and Prakash, S. (2020). Limnological studies of Semara Taal, a wetland of district Siddharthnagar, Uttar Pradesh, India. Journal of Fisheries and Life Science. 5(1): 15-19. 